\title{
Influence of Father's and Mother's Playfulness, Empathic Emotional Reaction, and the Child's Playfulness on the Child's Emotional Regulation: Examining the Mediated Moderation Effect
}

\author{
Ji-Hyun $\mathrm{Oh}^{1}$, Shee Hyeong Lim $^{2}$ \\ Assistant professor, Department of Counseling Psychology, Chosun University, Gwangju, Korea ${ }^{1}$ \\ Counselor, Holt Gwangju Counseling Center, Gwangju, Korea² \\ 아버지와 어머니의 놀이성, 공감적 정서반응과 유아의 놀이성이 유아의 \\ 정서조절에 미치는 영향 : 매개된 조절효과 \\ 오지현 ${ }^{1}$, 임시형 ${ }^{2}$ \\ 조선대학교 상담심리학과 조교수 ${ }^{1}$, 광주홀트심리상담센터 상담실장
}

Objectives: This study examined the mediated moderation effect of father's and mother's playfulness, and the child's playfulness, on the child's emotion regulation level, through father's and mother's empathic emotional reaction.

Methods: Participants included 300 mothers and 288 fathers of children aged 5-6 years. They completed questionnaires that included scales to assess their child's emotional regulation and playfulness, and their own empathic emotional reaction and playfulness. Data were analyzed using structural equation modeling.

Results: The relationship of father's and mother's playfulness with the child's emotional regulation level was mediated by the child's playfulness. Additionally, father's empathic emotional reaction level moderated the relationship between father's and the child's playfulness. Further, father's empathic emotional reaction level had a mediated moderation effect from father's playfulness to the child's emotional regulation, through the child's playfulness.

Conclusions: These results indicate the importance of father's empathic emotional reaction and the child's playfulness. Implications of these findings for parent counseling and parent education are discussed.

Keywords: father's playfulness, mother's playfulness, empathic emotional reaction, child's playfulness, child's emotional regulation

\section{Introduction}

정서조절은 전 생애에 걸쳐 발달하는데 영아기 이후 유아는 점차 체계적으로 정서를 표현하고 조절하는 능력이 증진한다

Corresponding Author: Ji-Hyun Oh, Assistant professor, Department of Counseling Psychology, Chosun University, Gwangju, Korea E-mail: ojh@chosun.ac.kr
(Buss \& Goldmith, 1998). 3세에서 6세는 전두엽이 급격히 발 달하고(C. Y. Kim, 2007), 정서를 이해하는 능력이 발달하는 결 정적인 시기이다(Cole, Ludy, \& Sullivan, 2008). 또한, 유아기는 주양육자와 관계가 중심이었던 단계에서 또래와 교사 등 다양

(C)The Korean Association of Child Studies

This is an Open Access article distributed under the terms of the Creative Commons Attribution Non-Commercial License (http:// creativecommons.org/licenses/by-nc/4.0) which permits unrestricted noncommercial use, distribution, and reproduction in any medium, provided the original work is properly cited. 
한 사람들과 관계를 확장해가는 시기로, 정서조절은 유아기에 습득해야 할 필수적 요소라 할 수 있다. 유아기 정서조절은 이 후 사회성 발달을 예측하는 요인이며(Denham, 2006), 또래 인 기도, 친사회성, 또래 유능성과 높은 연관성을 보인다. 반면, 정서조절능력의 결함은 사회적 위축(J. S. Park, Lim, \& Park, 2009), 또래관계 부적응(J. M. Jo, 2013; E. Lim \& Kim, 2011), 공격성과 충동적 문제행동(J.-Y. Kim, Doh, \& Kim, 2008)에 영 향을 주는 것으로 나타났다. 이러한 유아의 정서조절에 대한 선행연구를 살펴보면, 환경적 요인에는 부모와 애착(Cassidy, 1994; Oh, 2011), 어머니의 양육태도와 양육효능감(S. Yoon \& Sung, 2014), 어머니의 정서표현 및 유형(S. Y. Lee, 2011) 등, 부 모의 양육행동과 관련한 연구가 주로 이루어졌다. 또한, 유아 의 요인으로는 기질(K.-H. Kim, 2004), 실행기능과 같은 인지 적 특성이 강조된 바 있다(Kang \& Kim, 2018).

그러나 유아의 정서조절이 발달하는 경로를 이해하기 위 해서는 다양한 맥락적 요인을 이해해야 하며(Suveg, SouthamGerow, Goodman, \& Kendall, 2007), 개인내적 변수와 이에 영 향을 주는 환경적 변수를 모두 중요하게 고려해야 한다(Fox \& Calkins, 2003). 이와 같은 관점에 근거하여 Y.-H. Kim (2013), H. N. Kim과 Lee (2017), S. I. Yoon (2017)의 연구에서는 영, 유 아의 놀이성과 이에 영향을 주는 아버지와 어머니의 놀이성이 자녀의 정서조절에 영향을 주는 개인내적, 환경적 요인임을 밝혔다. 즉, 부모의 놀이성과 영, 유아의 놀이성이 높을수록 정 서인식 및 표현, 정서조절, 사회적 행동에 긍정적 영향을 주는 것으로 나타났다.

유아는 놀이를 통해 세상을 탐색하고, 학습하며 상호작용 한다. 놀이를 하며 억압된 정서를 표출하고 즐거움과 만족감 을 얻는다. 이러한 놀이행동을 일으키는 유아의 개인적 성향 또는 태도인 놀이성(playfulness)은 자발적이고 주도적인 내재 적 동기이며 즐거움의 표현으로 정의한다(Boyer, 1997). 언어 사용이 제한적인 유아는 놀이를 통해 자신의 감정을 적절히 표현하는 방법을 터득하고, 타인에 대한 조망능력 및 감정이 입이 향상되며 자기중심성에서 탈피한다(Woo, 2013). 구체적 으로 살펴보면 유아는 놀이를 통하여 긍정적, 부정적 정서를 경험하고 표현하며, 놀이성이 높은 유아는 또래관계에서 적절 한 정서표현을 하는 것으로 나타났다(M. K. Bae, 2012). 또한, 유아의 높은 놀이성은 정서지능, 자기-타인 정서 인식, 정서어 휘, 감정이입, 정서표현에 긍정적 영향을 미치고( $\mathrm{Han}, 2002$; Woo, 2013), 높은 자기-타인 정서조절 능력을 보였다(Y. Lim, 2010).

앞서 언급하였듯이 유아의 정서조절능력과 놀이성을 예
측하는 환경적 요인으로는 부모의 놀이성을 꼽을 수 있다. 유 아는 일상생활 속에 놀이를 통해 다양한 정서를 경험하고 조 절하는 능력을 증진하는데 이때 놀이제공, 놀이참여, 놀이대 상자의 역할을 하는 가장 가깝고 중요한 성인은 부모이다. 부 모가 유아의 놀이에 개입하는 정도를 놀이참여도라고 하는 데, 어머니의 놀이참여도는 유아의 정서조절과 자기조절능력 (Y. S. Choi, 2018; Hwang, 2012; C. S. Kim, 2010)을 증진시킨 다. 뿐만 아니라, 부모의 개인적 성향인 놀이신념과 놀이성 또 한 영, 유아의 정서발달에 영향을 주는 요인임을 밝혔다(Kelly, 2011; H. N. Kim \& Lee, 2017; Y.-H. Kim, 2013; J.-W. Lee, Lim, $\&$ Cho, 2009; S. I. Yoon, 2017).

성인의 놀이성은 재미와 유머, 자발성, 자유로움을 포함하 는 내재적 성향이나 태도로서 한 개인이 자신이 처한 상황에 적극적으로 대응하고 보다 즐겁고 유쾌한 삶을 추구하는 성 향으로 정의한다(Glynn \& Webster, 1992). 놀이성은 전 생애에 걸쳐 나타나는 내적 특질로서 아동만큼 성인의 놀이성 또한 중요함을 강조한 연구들이 보고되었다(Schaefer \& Greenberg, 1997). 특히, 놀이성이 높은 성인은 일, 관계 맺기에서도 즐거 움을 추구하며 놀이시간을 중요시하는데 이러한 특성이 부 모-자녀의 놀이 상호작용에서 잘 드러난다. 즉, 놀이성이 높 은 부모는 자녀의 눈높이에서 놀이에 참여하고 유아의 놀이 를 지지함으로써 놀이에 몰입하고 확장할 수 있게 할 뿐만 아 니라 유아가 자신의 감정을 표현하고 조절하는 데 도움을 줄 수 있을 것으로 예상된다. 이를 지지하는 선행연구로 놀이성 수준이 높은 부모는 자녀들의 놀이성에 긍정적 영향을 미쳤 고, 아동의 높은 놀이성은 적응력으로 이어졌다(Shen, Chick, $\&$ Pitas, 2017). 보다 구체적으로 Menashe-Greinberg와 AtzabaPoria (2017)는 부모-자녀 놀이에서 부모의 놀이성을 향상시켜 야 하는 필요성을 주장하였다. 즉, 유아의 부정적 정서와 관련 하여 부모의 양육행동 뿐만 아니라 놀이성 요인을 강조하였는 데, 어머니의 민감성, 구조화, 비침범과 같은 전형적 양육행동 에 어려움이 있을 때 어머니의 놀이성은 유아의 부정적 정서 를 완화시켜주는 중재역할을 하였다. 아버지는 상대적으로 어 머니보다 민감성이 낮고 구조화하는 양육역량이 부족하였지 만 놀이성이 보호요인으로 작용하여 유아의 부정적 정서가 낮 아지는 결과가 나타났다. 이를 통해 자녀와 놀이를 하는 동안 부모의 창의성, 상상력, 유머, 호기심을 활용하는 역량 즉, 부 모의 놀이성을 증진시킨다면 유아의 부정적 정서가 감소될 수 있음을 시사하였다.

또한, 유아의 발달에 영향을 미치는 아버지, 어머니의 놀이 성은 서로 다른 영향력을 미친다. 유아기 자녀와 놀이를 할 때 
아버지는 신체적이고 자극적인 놀이를 주로 하며 어머니는 언 어를 많이 사용하는 놀이 양상을 보인다(J. S. Kim, 2011). 뿐만 아니라 어머니와 아버지의 놀이성 수준과 놀이참여시간에서 차이가 나타나며(S. H. Lim, 2017), 어머니와 아버지 놀이성의 차이는 가족기능과 유아의 놀이성에 다르게 영향을 미치기 때 문에(O. M. Cho, 2005; Hwang, 2012; M. S. Lee, 2011), 본 연구 에서는 어머니와 아버지 집단을 구분하여 연구모형을 검증하 고자 한다.

한편, 선행연구 결과 놀이성 수준이 낮은 부모라 할지라 도 유아의 놀이성이 모두 낮아지는 것은 아니었다. 예를 들 면, 어머니의 놀이성과 유아의 놀이성 간 유의한 관련성을 보 이지 않았고(S.-M. Kim \& Choi, 2015), 어머니와 아버지의 놀 이성이 높았지만 유아의 놀이성 수준은 낮게 나타나기도 하 였다(Bu \& Kim, 2009). 반면에 아버지의 놀이성이 유아의 놀 이성에 긍정적 영향을 주고(J. S. Kim, 2011; K. S. Kim \& Park, 2009), 어머니의 놀이성 수준이 높을 경우 유아의 놀이성 또한 높게 나타났다(M. S. Lee, 2011). 이렇듯 아버지와 어머니의 놀 이성이 유아의 놀이성에 미치는 영향에 대한 비일관적 선행연 구 결과를 고려할 때 중재변수의 탐색이 필요함을 알 수 있다.

자녀의 정서표현에 대한 어머니의 지지적 반응과 긍정적 정서표현(H. Kim \& Kim, 2012; You, 2008), 그리고 아버지-자 녀, 어머니-자녀 간 긍정적 상호작용(E. A. Choi, 2005; Nam, 2005; Youell, 2008)이 유아의 놀이성에 영향을 미치는 요인임 을 밝힌 연구결과에 주목할 필요가 있겠다. 즉, 부모가 자녀에 게 공감적 정서반응을 빈번하게 보이는 상호작용이 많을수록 유아는 놀이에 더 즐겁게 몰입할 수 있으며 자발적이고 주도 적인 표현과 관련한 놀이성이 증진 될 수 있음을 예상하는 바 이다. 다시 말해, 부모의 놀이성과 유아의 놀이성의 관계에서 부모의 공감적 정서반응이 중재 역할을 할 것으로 추론해 볼 수 있겠다. 이는 어머니가 자녀에게 공감반응을 많이 할수록 유아의 즐거움 표현이 증진되는 결과(Song, 2009)와도 맥을 같 이한다. 또한, 어머니의 공감능력 중 상상하기가 유아의 놀이 성을 예측하는 요인으로 나타난 연구결과(Jung, Kim, \& Lee, 2015) 또한 고려해 볼 수 있다. 어머니의 상상하기는 실제가 아닌 가상의 상황에 대한 공감능력이므로(Barnett, 1990), 가상 적 특성이 포함된 놀이성에 긍정적 영향을 주는 것으로 해석 된다. 또한 상상하기 공감이 높은 어머니의 경우 유아의 상상 놀이에 대한 이해와 긍정적 인식이 높을 것으로 예상되며, 이 는 자녀를 상상놀이 친구로 참여하도록 이끌 수 있다(Gleason, 2005).

요컨대, 아버지와 어머니의 놀이성과 유아의 놀이성의 관
계는 공감적 정서반응 정도에 따라 달라질 수 있고, 또한 아버 지와 어머니의 놀이성과 유아의 정서조절 관계에 유아의 놀이 성이 매개역할을 할 것으로 추론해 볼 수 있겠다.

본 연구가설의 모형은 매개모형과 조절모형이 통합된 경 우이다. 최근 조절변수와 매개변수를 결합하여 변수들 간의 관계를 보다 세밀하게 파악하고자 하는 연구들이 이루어지 고 있다(B. R. Bae, 2015). 조절변수와 매개변수를 어떤 식으 로 결합하느냐에 따라 조절된 매개효과(moderated mediation) 와 매개된 조절효과(mediated moderation)로 나눌 수 있다. 독 립변수가 종속변수에 미치는 효과가 매개변수를 통해 나타나 고 매개효과가 조절변수에 따라 달라지는 경우를 조절된 매 개효과(moderated mediation) 또는 조건 간접효과(conditional indirect effect)라 하고 독립변수와 조절변수와의 상호작용항 이 매개변수를 통해 종속변수에 영향을 미치는 가를 검증하 는 것이 매개된 조절효과이다(Y. I. Cho, Kim, Han, \& Jo, 2015; Hayes, 2013; Morgan-Lopez \& MacKinnon, 2006; Muller, Judd, \& Yzerbyt, 2005; Preacher, Rucker, \& Hayes, 2007). 즉, 통계적 모델과 가설에 따라 조절된 매개효과와 매개된 조절효과를 구 분할 수 있다(B. R. Bae, 2015). 이러한 관점에서 본 연구는 예 측변수인 아버지, 어머니의 놀이성과 조절변수인 공감적 정 서반응의 상호작용 효과가 매개변수인 유아의 놀이성에 영향 을 주고 준거변수인 유아의 정서조절로 이어지는 효과를 검증 하고자 한다. 즉, 예측변수와 조절변수의 상호작용효과가 매 개변수에 의해서 전달되어 준거변수에 영향을 미치는 모형으 로 매개된 조절효과를 의미하며, 본 연구에서는 구조방정식으 로 분석하였다(Little, Card, Bovaird, Preacher, \& Crandall, 2007; Morgan-Lopez \& MacKinnon, 2006). 매개된 조절효과를 검증 하기 위해서는 모형에서 나타나는 매개효과와 조절효과가 각 각 통계적으로 유의미해야 하므로 매개효과와 조절효과를 검증하고 두 모형을 결합한 매개된 조절효과를 검증하였다. 본 연구의 연구문제는 아래와 같고, 연구모형과 통계모형은 figure1과 figure2에 제시하였다.

\section{연구문제 1}

아버지의 놀이성, 유아의 놀이성, 유아의 정서조절 관계에서 아버지의 공감적 정서반응의 매개된 조절효과가 나타나는가?

\section{연구문제 2}

어머니의 놀이성, 유아의 놀이성, 유아의 정서조절 관계에서 어머니의 공감적 정서반응의 매개된 조절효과가 나타나는가? 


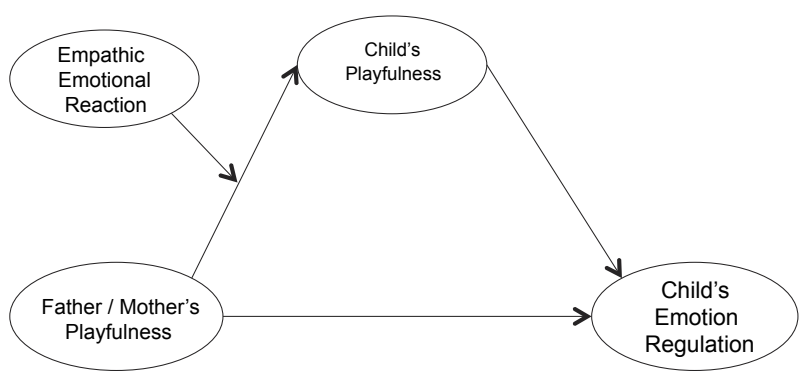

Figure 1. Conceptual model.

\section{Methods}

\section{연구대상}

본 연구는 $\mathrm{A}, \mathrm{B}, \mathrm{C}$ 지역에 소재한 유아교육기관을 임의로 선 정하여 5,6세 유아와 그들의 아버지와 어머니를 대상으로 실 시하였다. 유아기는 신체 및 언어발달로 인해 자율성이 높아 지고 자기주장이 강해지는 시기로 특히 부정적 정서의 표출이 많아진다(Partridge \& Lerner, 2007). 또한 정서의 사회화 즉, 정 서를 조절하고 학습하는 능력이 발달하는 결정적 시기임을 강 조한 연구(Cole et al., 2008)를 근거로 연구대상을 선정하였다. 유아와 아버지, 어머니 집단의 인구통계학적 특성은 Table 1에 제시하였다.

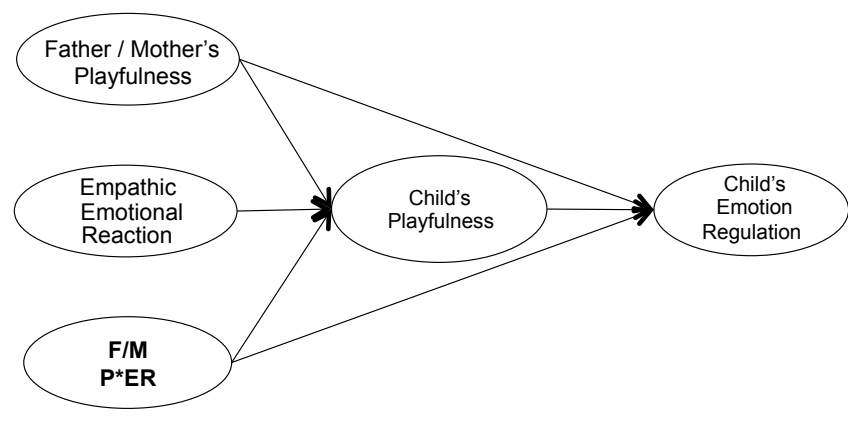

Figure 2. Statistical model.

\section{연구도구}

\section{유아의 정서조절}

본 연구에서는 유아의 정서조절을 측정하기 위해 Shields와 Ciccihetti (1997)가 개발한 Emotion Regulation Checklist (ERC) 를 번안한 J.-Y. $\operatorname{Kim}$ (2007)의 척도를 사용하였다. 본 측정도구 는 Likert식 4점 척도로 불안정/부정적정서(15문항)와 정서통 제(9문항)의 하위요인으로 이루어져 있으며, 주 양육자가 보 고하는 방식이다. '불안정/부정적 정서'의 점수가 높을수록 부 정적 정서가 나타나는 상황에서 자신의 기분변화에 따라 정서 적 강도를 적절히 조절하지 못함을 의미하고, '정서통제'의 점 수가 높을수록 자신의 마음을 조절하고 타인의 감정을 이해하

Table 1

Demographic Characteristics

\begin{tabular}{|c|c|c|c|}
\hline & \multirow[b]{2}{*}{ Variables } & \multicolumn{2}{|c|}{ Frequency (Percentile) } \\
\hline & & Father & Mother \\
\hline \multirow[t]{3}{*}{ Parent's age } & $20 s$ & $5(1.7)$ & $17(5.7)$ \\
\hline & $40 s$ & $149(51.7)$ & $93(31.0)$ \\
\hline & Over 50s & $12(4.2)$ & $6(2.0)$ \\
\hline \multirow{4}{*}{ Educational level } & High school & $68(23.6)$ & $81(27.0)$ \\
\hline & College & $192(66.7)$ & $187(62.3)$ \\
\hline & Graduate school & $22(7.6)$ & $23(7.7)$ \\
\hline & Other & $3(1.1)$ & $3(1.0)$ \\
\hline Child's age & 5 year & $143(49.7)$ & $151(50.3)$ \\
\hline
\end{tabular}

Note. $N=288$ (Father); 300 (Mother). 
는 능력이 높음을 의미한다. 단, 본 연구에서는 불안정/부정적 정서의 문항들을 역 코딩하여 점수가 높을수록 유아의 정서조 절 능력이 높은 것을 의미한다.

$$
\text { 유아의 놀이성 }
$$

본 연구에서는 유아의 놀이성을 측정하기 위해 M. S. Kim, Kim 과 Park (2012)이 개발한 유아용 놀이성 척도를 사용하였다. 본 측정도구는 Likert식 5점 척도(전혀 그렇지 않다[1점] 매우 그 렇다[5점])로 주 양육자가 보고한다. 하위요인은 주도적 참여 (15문항), 인지적 융통성(9문항), 즐거움의 표현(6문항), 자발적 몰입(5문항)으로 구성되어있다. '주도적 참여'는 유아가 놀이 과정에서 또래와의 협력 정도, 나누기, 접촉 등에 대한 내용이 고 '인지적 융통성'은 유아의 독창성, 문제해결력을 포함한다. 또한 ‘즐거움의 표현’은 놀이과정에서 유아가 기쁨, 즐거움, 성 취에 대한 만족, 미소를 나타내는 정도를 나타내고, '자발적 몰 입’은 놀이에서 유아의 적극성, 능동성을 의미한다.

$$
\text { 아버지와 어머니의 놀이성 }
$$

본 연구에서는 아버지와 어머니의 놀이성 측정을 위해 K. S. $\operatorname{Kim}$ (2002)이 타당도 검증을 실시한 부모 놀이성 척도를 사용 하였다. 본 측정도구는 Likert식 4점 척도(전혀 그렇지 않다 $[1$ 점] 매우 그렇다[4점])이며 유머와 위트(6문항), 재미탐닉(8 문항), 즐거움과 낙천 지향적 성향(5문항)의 3 가지 하위요인으 로 구성되어있다. '유머와 위트'는 사회적 관계를 좀 더 즐겁게 만들기 위해 놀이성을 사용하거나 좋은 의도의 장난을 즐기 는 성향을 나타낸다. '재미탐닉'의 경우 "나는 집에서 아이들 과 함께 노는 것을 매우 좋아하며 즐긴다.” 등과 같은 문항이 있고 일상에서 놀이를 위한 시간을 확보해 두는 성향을 뜻한 다. ‘즐거움과 낙천지향적 성향'은 일상적인 삶과 상호작용에 서 즐거움을 잘 찾아내고 낙관적인 성향을 나타낸다. 각 하위 요인의 점수가 높을수록 아버지와 어머니의 놀이성이 높음을 의미한다.

\section{아버지와 어머니의 공감적 정서반응}

본 연구에서는 아버지와 어머니의 공감적 정서반응을 측정하 기 위해 Y.-J. Jo (2010)가 개발하고 타당화한 부모공감 척도(부 모용)를 사용하였고, 해당척도의 하위요인 중 본 연구의 목적 에 부합하는 공감적 정서반응 5 문항을 활용하였다. 단, 원 척
도는 청소년 자녀를 키우는 부모를 대상으로 개발된 척도이므 로 유아기 자녀를 둔 부모에게도 적합한지를 평가하기 위해 아동심리치료 전공 교수 1 인과 유아 교육 및 심리치료 기관에 서 10 년 이상 종사한 석.박사 3 인에게 내용타당도 검증을 확 인하였다. 평정자들의 문항 적합성(5점) 평균점수가 4.5 4.7 로 나타나 원척도 5 문항을 모두 동일하게 사용하였다. 예를 들면, “나에게는 아이를 염려하는 따뜻한 마음이 있다.", "아이 가 신나는 일을 이야기하면 나도 기분이 좋아진다.” 등의 문항 으로 점수가 높을수록 자녀의 정서표현에 공감적인 반응이 많 음을 의미한다.

\section{연구절차}

본 연구를 위한 자료는 유아교육기관 9곳에서 두 차례의 직접 방문을 통해 수집하였다. 자료 수집을 위해 해당 기관의 책임 자와 교사, 부모들에게 연구의 목적과 자료의 활용 목적에 대 해 구체적인 설명을 실시하였고 이에 동의한 기관과 부모에 한하여 각 400 부의 설문지를 배포하였다. 설문지는 각 반의 담임교사를 통해 배부하였고 각 가정에서 아버지와 어머니가 작성하여 제출된 응답지를 연구자가 재방문하여 최종 회수하 였다. 회수된 설문지는 어머니 308 부, 아버지 300 부를 회수하 였다. 이 중에 불성실하거나 누락된 문항이 많은 설문지를 제 외하여 어머니 300 부, 아버지 288 부의 설문지를 최종분석에 사용하였다.

\section{자료분석}

본 연구에서 수집된 자료는 AMOS 20.0 (IBM Co., Armonk, $\mathrm{NY})$ 을 이용하여 구조방정식 모형을 분석하였다. 먼저, 모형의 적합도를 평가하기 위해서 $\chi^{2}$ 값과 관련 자유도 $(d f)$, 증분적합 지수(IFI, TLI, CFI), 절대적합지수(GFI, RMSEA)를 살펴보았 다. $\chi^{2} / d f$ 값은 3 이하일 경우 안정적이라고 보고하며 IFI, TLI, $\mathrm{CFI}, \mathrm{GFI}$ 의 경우는 .90 이상이면 좋은 적합도를 보인다고 할 수 있다. RMSEA의 경우 .09 이하는 좋은 적합도로 해석한다 (G. S. Kim, 2010). 다음으로, 경로의 효과성을 분해하고 매개 효과의 통계적 유의성을 검증하기 위해 Bootstrapping방법을 적용하였다. 이는 간접효과의 값은 정규분포를 가정하지 못 하는 경우가 많기 때문에 경험적 분포를 사용하여 정확한 신 뢰구간을 산출하는 Bootstrapping방법이 보다 적합하다는 제 언(Preacher \& Selig, 2012; Shrout \& Bloger, 2002)을 근거로 분 석하였다. 또한, 조절효과의 유의성 검증을 위해서 $\mathrm{AMOS}$ 에 
서 조절효과를 분석하는 접근(Ping, 1995a; Ping, 1995b)을 적 용하였고, 상호작용 효과 그래프 작성과 기울기 유의성 검증

은 Dawson (2014), Dawson과 Richter (2006)가 제안한 방법으 로 분석하였다. 마지막으로 매개된 조절효과에 대한 유의성 검증은 Hayes (2013)의 접근법을 적용하였다. Hayes (2013)는 간접효과의 유의성을 검토해 매개된 조절효과를 검증할 수 있 다고 주장하며, 이러한 접근법은 Morgan-Lopez와 MacKinnon (2006), Fairchild와 MacKinnon (2009)의 주장과도 같다.

\section{Results}

\section{측정모형의 타당도}

구조방정식 모델을 분석하기 위해서 Anderson과 Gerbing (1988) 의 2 단계 접근방법을 적용하였다. 즉, 첫 번째로 측정모형의 적 합성 판단과 타당성 검증을 한 후 두 번째로 구조모형 분석을 통해 적합성 판단과 요인 간 유의성 판단을 하는 절차이다. 측 정모형을 분석하는 목적은 구성개념과 그것을 측정하는 변수 사이의 일치성에 관한 것으로 관측변수가 잠재변수를 잘 설명 하고 있는지에 대한 검증이다. 이는 동일한 개념을 측정하는 문 항들 사이의 일관성 정도를 의미하는 집중 타당성 검증으로 확 인 할 수 있다. 집중 타당성을 평가하는 방법으로는 요인부하
량 값과 유의성, 개념 신뢰도(Construct Reliability [CR])와 평균 분산추출지수(Average Variance Extracted [AVE])가 있다. 요인 부 하량은 최소 .50 이상의 값이 바람직하며 .70 이상이면 높은 수 치라고 볼 수 있다. 또한, 개념 신뢰도(CR)와 평균분산추출지수 (AVE)가 높다는 것은 해당하는 요인에 대한 측정변수들의 내 적일치도가 높다는 것을 의미하여 $\mathrm{CR}$ 은 .70이상, $\mathrm{AVE}$ 는 .50 이 상이면 높은 신뢰도에 해당한다(G. S. Kim, 2010).

또한, 구조방정식 모델에서는 측정항목 수가 증가할수록 모델의 복잡성이 증가하고 이는 많은 양의 표본의 크기가 필 요하게 된다. 표본의 크기가 제한된 경우라면 모델의 복잡성 을 낮추고 단순화하는 과정도 필요하다. 이 때 문항묶음(item parceling)을 통해 모델의 간명성, 경제성을 높일 수 있다. 단, 문항묶음은 장단점이 있기 때문에 연구자의 판단이 필요하다 (Yu, 2015). 본 연구에서는 제한된 표본의 크기와 모델의 복잡 성을 고려해 아버지와 어머니의 놀이성, 유아의 놀이성, 정서 조절은 다차원 접근법(Kishton \& Widaman, 1994; Little et al., 2007)을 적용하여 하위요인별로 항목묶음을 하였다. 공감적 정서반응은 문항이 5 개인 점을 고려해 전 문항을 측정변수로 설정하였다.

\section{아버지 집단의 측정모형 타당도}

먼저, 아버지 집단의 확인적 요인분석을 실시하였고 적합도

Table 2

Convergent Validity (Fathers' Group)

\begin{tabular}{|c|c|c|c|c|c|}
\hline Latent variables & Measurement variables & $\beta$ & $t$-value & $\mathrm{CR}$ & AVE \\
\hline \multirow[t]{3}{*}{ Father's playfulness } & Pleasure \& direction of optimism & .680 & Fix & .904 & .759 \\
\hline & Pursuit of fun & .742 & $9.829^{* * *}$ & & \\
\hline & Humor \& wit & .773 & $9.980^{* * *}$ & & \\
\hline \multirow[t]{5}{*}{ Father's empathic emotional reaction } & Father's empathic emotional reaction 1 & .677 & $8.527^{* * *}$ & .985 & .929 \\
\hline & Father's empathic emotional reaction 2 & .627 & $8.101^{* * *}$ & & \\
\hline & Father's empathic emotional reaction 3 & .646 & $8.267^{* * *}$ & & \\
\hline & Father's empathic emotional reaction 4 & .777 & $9.198^{* * *}$ & & \\
\hline & Father's empathic emotional reaction 5 & .591 & Fix & & \\
\hline $\begin{array}{l}\text { Father's playfulness } \\
\times \text { empathic emotional reaction }\end{array}$ & $\begin{array}{l}\text { Father's playfulness } \\
\times \text { empathic emotional reaction }\end{array}$ & .490 & Fix & - & - \\
\hline \multirow[t]{4}{*}{ Child's playfulness } & Leading participation & .846 & Fix & .88 & .657 \\
\hline & Cognitive flexibility & .795 & $15.085^{* * *}$ & & \\
\hline & Expression of joy & .632 & $11.231^{* * *}$ & & \\
\hline & Spontaneous immersion & .816 & $15.573^{* * *}$ & & \\
\hline \multirow[t]{2}{*}{ Child's emotion regulation } & Unstable and negative emotion & .360 & Fix & .784 & .661 \\
\hline & Emotional control & .805 & $4.603^{* * *}$ & & \\
\hline
\end{tabular}

${ }^{* * *} p<.001$. 
지수의 값은 $\chi^{2} / d f$ 값이 $2.014\left(\chi^{2}=165.186, d f=82, p=.000\right)$, IFI .943, TLI .925, CFI .942, GFI .930, RMSEA .05로 모두 좋 은 적합도 기준에 포함된다. 또한, 확인적 요인분석을 통해 요 인부하량 값을 산출하고 유의성 검증을 한 결과와 CR과 $\mathrm{AVE}$ 를 구하는 공식(Yu, 2012)으로 계산한 결과를 Table 2에 제시하 였다. Table 2 에 따르면 측정변수의 요인부하량은 .50 이상으 로 나타났고, CR .78 이상, AVE .65 이상으로 높게 나타나 집 중타당성을 검증하였다. 단, 유아의 불안정 및 부정적 변수의 요인 부하량이 .36으로 기준치에 다소 미치지 못하는 결과이 나 측정변수 사이의 일관성 정도를 알아보는 CR과 $\mathrm{AVE}$ 값이 높은 편으로 나타나 삭제 없이 분석에 활용하였다.

\section{어머니 집단의 측정모형 타당도}

다음으로, 어머니 집단의 확인적 요인분석을 실시하였고 적 합도 지수의 값은 $\chi^{2} / d f$ 값이 $2.311\left(\chi^{2}=187.156, d f=81, p=\right.$ .000), IFI .919, TLI .902, CFI .917, GFI .921, RMSEA .06으 로 모두 양호하게 나타났다. 또한, Table 3에는 확인적 요인분 석을 통해 요인부하량 값을 산출하고 유의성 검증을 한 결과 와 $\mathrm{CR}$ 과 $\mathrm{AVE}$ 를 구하는 공식으로 계산한 결과를 제시하였다. Table 3에 따르면 측정변수의 요인부하량은 .50이상으로 나타
났고, $\mathrm{CR} .78$ 이상, AVE .65 이상으로 높게 나타나 집중타당 성을 검증하였다. 단, 유아의 불안정 및 부정적 변수의 요인 부 하량이 . 35 로 기준치에 다소 미치지 못하는 결과이나 측정변 수 사이의 일관성 정도를 알아보는 CR값과 $\mathrm{AVE}$ 값이 높은 편 으로 나타나삭제 없이 분석에 활용하였다.

\section{구조모형 분석}

아버지의 놀이성, 유아의 놀이성, 유아의 정서 조절 관계에서 아버지의 공감적 정서반응의 매 개된 조절효과

본 연구에서 Morgan-Lopez와 MacKinnon (2006), Little 등 (2007)이 제안한 매개된 조절효과 검증절차를 따라 매개모 형, 조절모형, 매개된 조절모형 순서로 구조방정식 모형을 분 석하였고, 각 연구모형의 모델 적합도 지수는 Table 4 와 같다.

아버지의 놀이성과 유아의 정서조절 관계에서 유아 놀이성의 매개효과 아버지의 놀이성, 유아의 정서조절 간 관계에서 유 아 놀이성의 매개모형에 대한 구조방정식 분석 결과를 Table 5 와 Figure 3에 제시하였다. Table 5와 Figure 3에 따르면, 아버지

Table 3

Convergent Validity (Mothers' Group)

\begin{tabular}{|c|c|c|c|c|c|}
\hline Latent variables & Measurement variables & $\beta$ & $t$-value & CR & AVE \\
\hline \multirow[t]{3}{*}{ Mother's playfulness } & Pleasure $\&$ direction of optimism & .577 & Fix & .889 & .729 \\
\hline & Pursuit of fun & .695 & $7.860^{* * *}$ & & \\
\hline & Humor \& wit & .732 & $7.959^{* * *}$ & & \\
\hline \multirow[t]{5}{*}{ Mother's empathic emotional reaction } & Mother's empathic emotional reaction 1 & .607 & $14.6^{* * *}$ & .982 & .919 \\
\hline & Mother's empathic emotional reaction 2 & .500 & $8.101^{* * *}$ & & \\
\hline & Mother's empathic emotional reaction 3 & .602 & $8.267^{* * *}$ & & \\
\hline & Mother's empathic emotional reaction 4 & .725 & $9.198^{* * *}$ & & \\
\hline & Mother's empathic emotional reaction 5 & .503 & Fix & & \\
\hline $\begin{array}{l}\text { Mother's playfulness } \\
\times \text { empathic emotional reaction }\end{array}$ & $\begin{array}{l}\text { Mother's playfulness } \\
\times \text { empathic emotional reaction }\end{array}$ & .590 & Fix & - & - \\
\hline \multirow[t]{4}{*}{ Child's playfulness } & Leading participation & .832 & Fix & .894 & .681 \\
\hline & Cognitive flexibility & .781 & $14.668^{* * *}$ & & \\
\hline & Expression of joy & .634 & $11.330^{* * *}$ & & \\
\hline & Spontaneous immersion & .810 & $15.295^{* * *}$ & & \\
\hline \multirow[t]{2}{*}{ Child's emotion regulation } & Unstable and negative emotion & .350 & Fix & .794 & .678 \\
\hline & Emotional control & .836 & $4.356^{* * *}$ & & \\
\hline
\end{tabular}

${ }^{* * *} p<.001$. 
의 놀이성은 유아의 정서조절 능력에 직접적 효과가 나타나지 않았으나 아버지의 놀이성은 유아의 놀이성을 예측하였고 $(\beta$ $=.302, p<.001)$, 유아의 놀이성은 유아의 정서조절 능력에 $(\beta$ $=.767, p<.001)$ 유의한 영향을 미쳤다. 또한, 매개효과의 유의 성을 검증한 결과 제시한 신뢰구간이 0 을 포함하지 않으면 매 개효과가 통계적으로 유의함을 의미하는데(Shrout \& Bolger, 2002), 아버지의 놀이성이 유아의 놀이성을 거쳐 유아의 정서 조절에 영향을 미치는 간접효과가 유의한 것으로 나타났다 (.232, Bias-corrected $\mathrm{CI}=.127$.367). 즉, 아버지의 놀이성은 유아의 놀이성을 매개로 유아의 정서조절을 예측하는 완전매 개모형으로 나타났다.
아버지의 놀이성과 유아의 놀이성 관계에서 아버지의 공감적 정서반응의 조절효과 아버지의 놀이성과 유아의 놀이성 관 계에서 아버지의 공감적 정서반응의 조절 모형을 Ping (1995a; 1995b)이 제안한 구조방정식 접근법으로 분석하였고, Dawson 과 Richter (2006)가 제시한 상호작용 효과의 기울기 유의성 검 증 방법을 적용하였다. 우선, 유아의 놀이성에 대한 아버지의 놀이성과 공감적 정서반응의 상호작용 효과에 대한 구조방정 식 분석 결과는 Table 6과 Figure 4에 제시하였다. 아버지의 놀 이성은 유아의 놀이성을 유의미하게 예측하였으나 $(\beta=.331, p$ $<.001)$, 아버지의 공감적 정서반응은 유아의 놀이성에 유의한 영향을 미치지 않았다. 반면, 아버지의 놀이성과 아버지의 공

Table 4

Fit Indices of the Observed Models

\begin{tabular}{ccccccccc}
\hline $\begin{array}{c}\text { Model/ Fit } \\
\text { indices }\end{array}$ & $\chi^{2}$ & $d f$ & $\chi^{2} / d f$ & TLI & IFI & CFI & GFI & RMSEA \\
\hline 1 & 61.926 & 24 & 2.580 & .939 & .960 & .959 & .953 & .074 \\
2 & 110.902 & 60 & 1.848 & .947 & .960 & .960 & .947 & .054 \\
3 & 161.163 & 82 & 1.965 & .929 & .945 & .944 & .932 & .058 \\
\hline
\end{tabular}

Note. $N=288$.

$1=$ mediated model; $2=$ moderation model $3=$ mediated moderation model.

Table 5

Path Estimates of Latent Variables

\begin{tabular}{lcccc}
\hline \multicolumn{1}{c}{ Path of latent variables } & $B$ & $\beta$ & $S E$ & $t$-value \\
\hline Father's playfulness $\rightarrow$ Child's emotion regulation & -.086 & -.075 & .082 & -1.051 \\
Father's playfulness $\rightarrow$ Child's playfulness & 1.351 & .302 & .330 & 4.098 \\
Child's playfulness $\rightarrow$ Child's emotion regulation & .196 & .767 & .048 & 4.118 \\
\hline
\end{tabular}

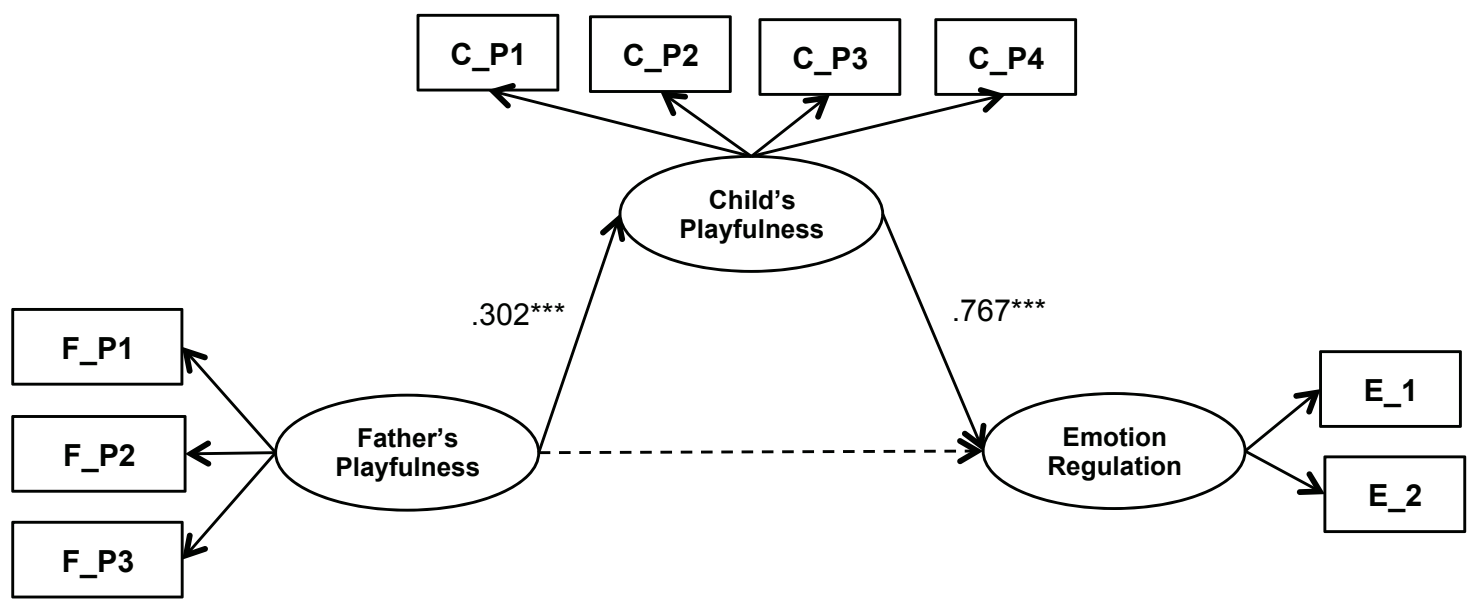

Figure 3. The mediated model.

${ }^{* * *} p<.001$. 
Table 6

Path Estimate of Latent Variables

\begin{tabular}{lccccc}
\hline \multicolumn{1}{c}{ Path of latent variables } & $B$ & $\beta$ & $S E$ & $t$-value & $p$ \\
\hline Father's playfulness $\rightarrow$ Child's playfulness & 1.395 & .331 & .429 & 3.255 & .001 \\
Father's empathic emotional reaction $\rightarrow$ Child's playfulness & .283 & .015 & 1.757 & .161 & .872 \\
Father's playfulness $x$ Father's empathic emotional reaction $\rightarrow$ Child's playfulness & -1.083 & -.167 & .498 & -2.174 & .030 \\
\hline
\end{tabular}

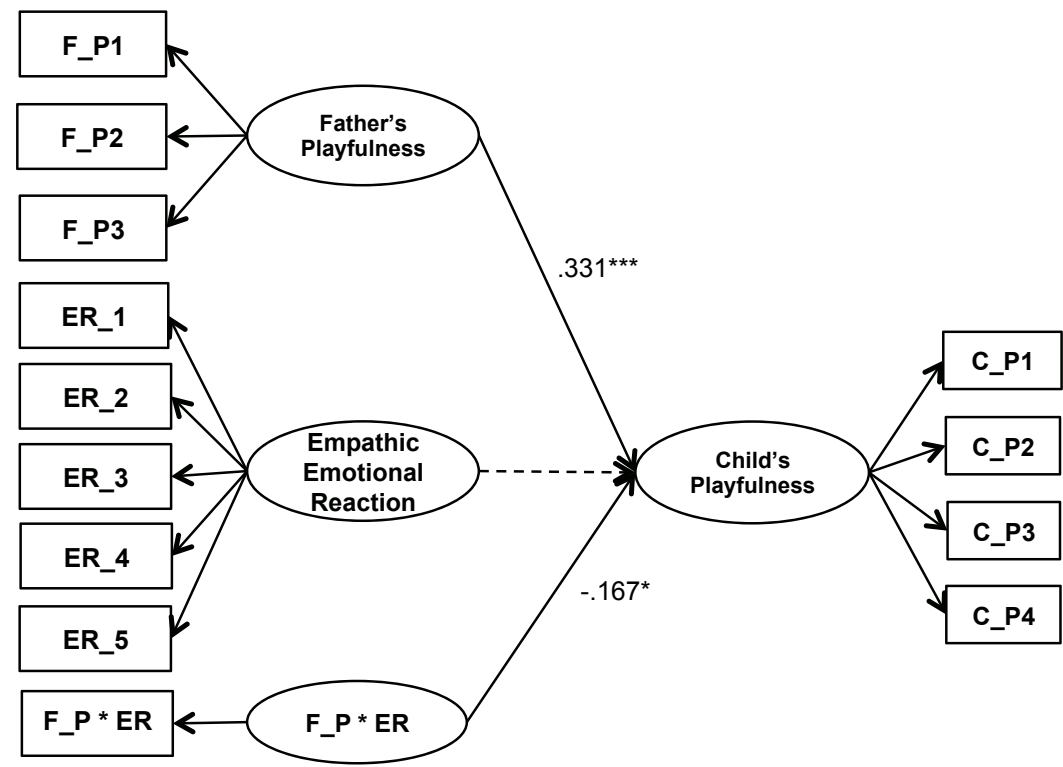

Figure 4. The moderation model.

${ }^{*} p<.05 .{ }^{* * *} p<.001$.

감적 정서반응의 상호작용 변수는 유아의 놀이성에 유의미한 영향을 주는 것으로 나타났다 $(\beta=-.167, p<.05)$. 다시 말해 공 감적 정서반응의 조절효과가 통계적으로 유의미하게 나타남 을 의미하며, 이들의 회귀계수를 검토한 결과 아버지의 공감 적 정서반응은 대립효과를 보이는 것으로 나타났다. 대립효과 는 독립변수와 조절변수는 종속변수에 동일한 방향으로 영향 을 미치나 상호작용 효과는 반대방향으로 영향을 미치는 것을 의미한다(B. R. Bae, 2015). 보다 심층적으로 살펴보기 위해 단 순기울기를 검증한 결과는 Table 7, Figure 5에 제시하였다.

Table 7에 제시한 바와 같이 평균값과 \pm 1 표준편차 집단에 서 유아의 놀이성에 미치는 효과는 유의한 것으로 나타났고 $(t=2.093, p<.05)$, 이를 Figure 5로 나타내면 다음과 같다. Figure 5에서 볼 수 있듯이 아버지의 놀이성이 낮을수록 아이 의 놀이성도 감소하는데 아버지의 공감적 정서반응이 평균보 다 적을 경우 유아의 놀이성은 더 감소하는 것으로 나타났다. 다시 말해, 아버지의 놀이성이 낮을 경우에도 공감적 정서반 응을 평균보다 많이 하는 아버지의 경우 유아의 놀이성은 높
아진다. 이는 기울기 검증을 통해 공감적 정서반응이 적은 아 버지에 비해 통계적으로 유의미한 기울기 차이가 나타남을 확 인할 수 있었다.

아버지의 놀이성, 공감적 정서반응과 유아의 놀이성이 유아의 정서조절에 미치는 영향: 매개된 조절효과 매개된 조절효과 의 분석절차에 따라 앞서 매개모형과 조절모형의 효과가 유의 하게 나타났고 다음으로 두 모형이 결합된 매개된 조절효과를 검증하였다. Table 8 과 Figure 6 에 제시한 바와 같이 아버지의 놀이성 $(\beta=.312, p<.01)$, 아버지의 놀이성과 공감적 정서반응 의 상호작용 변수 $(\beta=-.165, p<.05)$ 는 유아의 놀이성을 유의 미하게 예측하는 것으로 나타났고 유아의 놀이성 또한 유아의 정서조절 $(\beta=.739, p<.001)$ 에 유의미한 영향을 미치는 것으 로 나타났다. 단, 아버지의 놀이성, 그리고 아버지의 놀이성과 공감적 정서반응의 상호작용 변수는 유아의 정서조절에 대한 직접효과는 나타나지 않았다.

다음으로 간접효과의 유의성을 검증한 결과, 아버지의 놀 
Table 7

Results of the Simple Slope Analyses

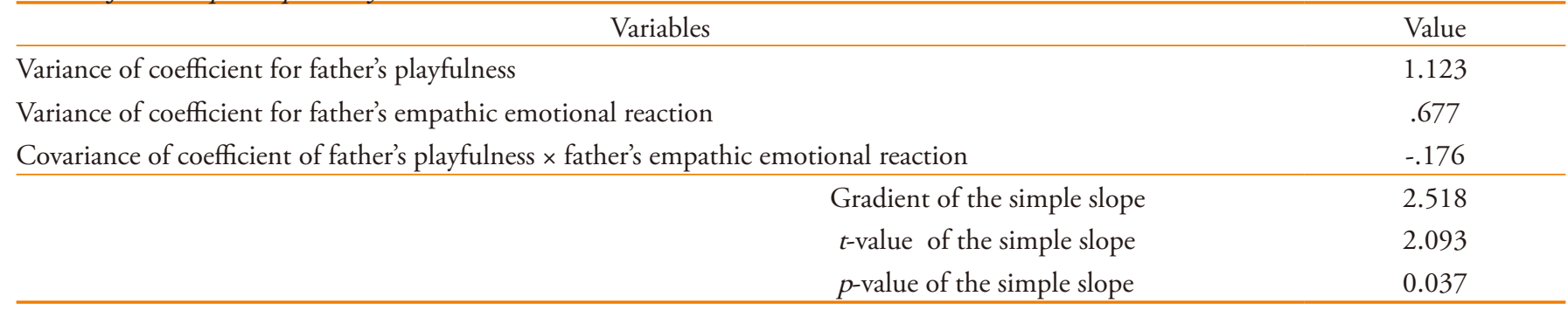

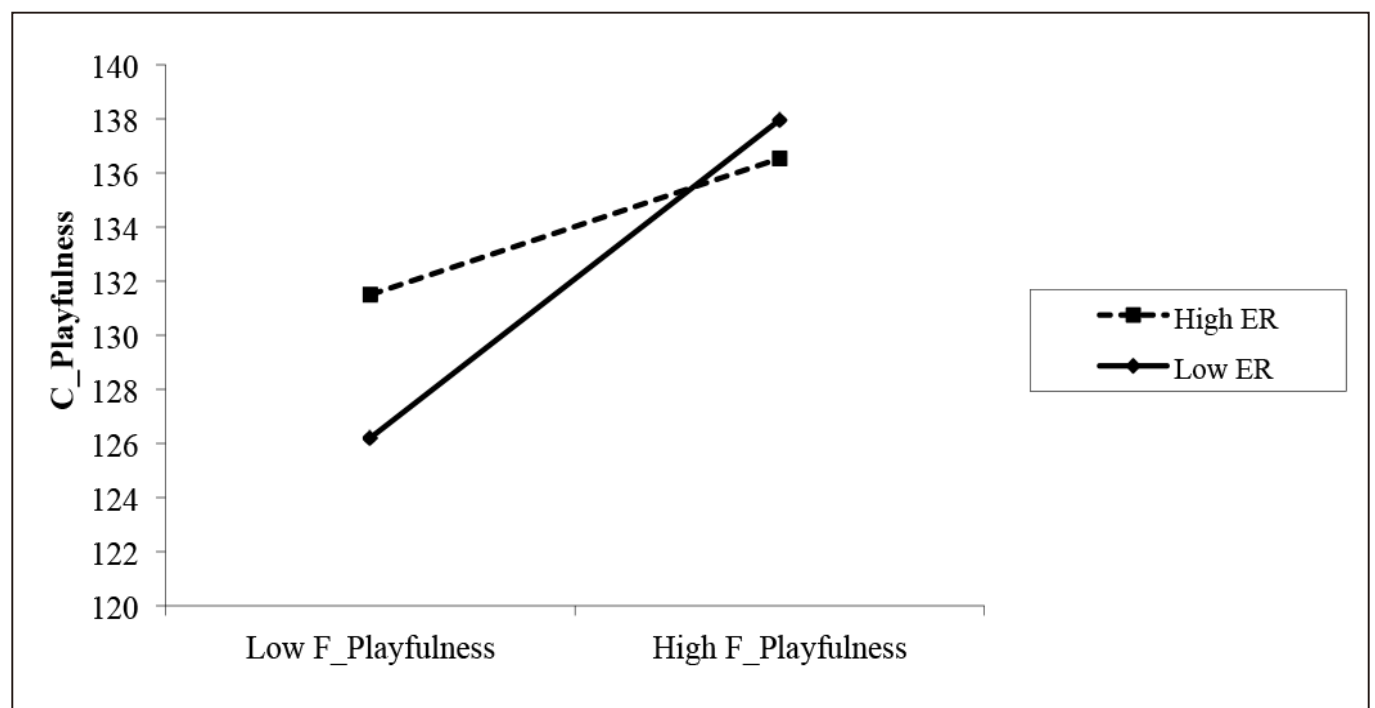

Figure 5. Interaction effect between variables.

Table 8

Path Estimate of latent variables

\begin{tabular}{lrrrrr}
\multicolumn{1}{c}{ Path of latent variables } & $B$ & $\beta$ & $S E$ & $t$-value & $p$ \\
\hline Father's playfulness $\rightarrow$ Child's playfulness & 1.356 & .312 & .438 & 3.093 & .002 \\
Father's empathic emotional reaction $\rightarrow$ Child's playfulness & .721 & .037 & 1.803 & .400 & .689 \\
Father's playfulness $\times$ Father's empathic emotional reaction $\rightarrow$ Child's playfulness & -1.103 & -.165 & .515 & -2.142 & .032 \\
\hline Child's playfulness $\rightarrow$ Child's emotion regulation & .186 & .739 & .046 & 4.005 & .000 \\
Father's playfulness $\times$ Father's empathic emotional reaction $\rightarrow$ Child's emotion regulation & -.106 & -.063 & .118 & -.896 & .370 \\
Father's playfulness $\rightarrow$ Child's emotion regulation & -.035 & -.031 & .078 & -.442 & .658 \\
\hline
\end{tabular}

이성이 유아의 놀이성을 거쳐 유아의 정서조절에 영향을 미 치는 간접효과가 유의한 것으로 나타났고(.230, Bias-corrected $\mathrm{CI}=.098 \sim .411)$, 아버지의 놀이성과 공감적 정서반응의 상호 작용 변수 또한 유아의 놀이성을 예측하며 이는 유아의 정서 조절로 이어지는 간접효과가 유의하게 나타났다(-.063, Biascorrected CI = -.285 -.009). 따라서 아버지의 놀이성, 공감적
정서반응 그리고 아버지의 놀이성과 공감적 정서반응의 상호 작용 변수가 유아의 정서조절에 미치는 영향에서 유아의 놀이 성이 매개변수로 투입된 매개된 조절효과가 유의한 것으로 나 타났다. 


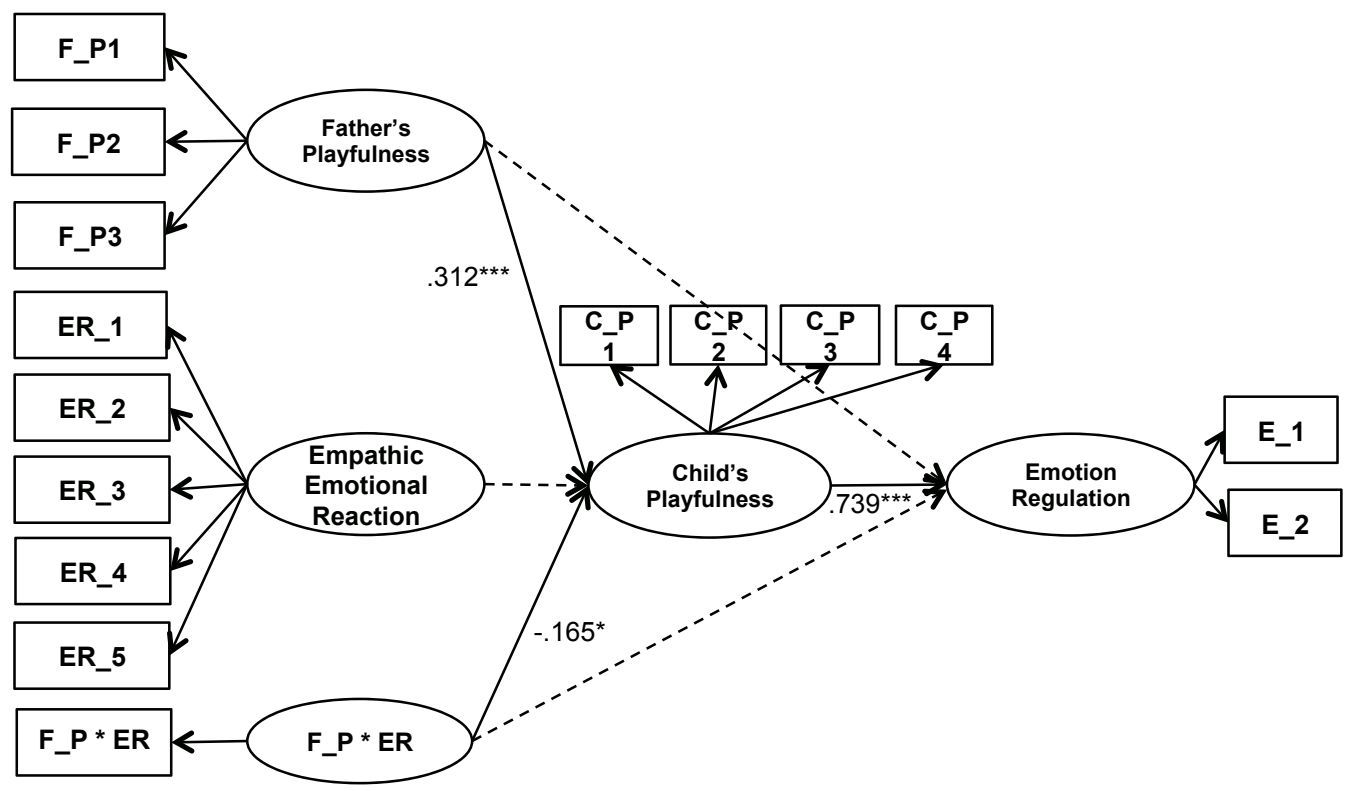

Figure 6. Mediated moderation effects.

${ }^{*} p<.05 .{ }^{* * *} p<.001$

Table 9

Fit Indices of the Observed Models

\begin{tabular}{ccccccccc}
\hline Model/ Fit indices & $\chi^{2}$ & $d f$ & $\chi^{2} / d f$ & TLI & IFI & CFI & GFI & RMSEA \\
\hline 1 & 83.969 & 24 & 3.499 & .902 & .936 & .935 & .939 & .09 \\
2 & 128.644 & 60 & 2.144 & .919 & .938 & .937 & .939 & .06 \\
3 & 187.156 & 81 & 2.311 & .902 & .919 & .917 & .921 & .06 \\
\hline
\end{tabular}

Note. $N=300$.

$1=$ mediated model; $2=$ moderation model; $3=$ mediated moderation model.

어머니의 놀이성, 유아의 놀이성, 유아의 정서 조절 관계에서 어머니의 공감적 정서반응의 매 개된 조절효과

앞서 언급한 매개된 조절효과 검증절차를 따라 어머니 집단의 매개모형, 조절모형, 매개된 조절모형 순서로 구조방정식 모 형을 분석하였고, 각 연구모형의 모델 적합도 지수는 Table 9 와 같다.

어머니의 놀이성과 유아의 정서조절 관계에서 유아 놀이성 의 매개효과 어머니의 놀이성과 유아의 정서조절 관계에 서 유아 놀이성의 매개모형에 대한 구조방정식 분석 결과를 Table10과 Figure7에 제시하였다. Table 10에 제시한 바와 같이, 어머니의 놀이성은 유아의 정서조절 능력에 직접적 효과가 나 타나지 않았으나, 어머니의 놀이성은 유아의 놀이성을 예측하
였고 $(\beta=.463, p<.001)$, 유아의 놀이성은 유아의 정서조절 능 력에 $(\beta=.752, p<.001)$ 유의한 영향을 미쳤다. 또한, 매개효과 의 유의성 검증결과 어머니의 놀이성이 유아의 놀이성을 거쳐 유아의 정서조절에 영향을 미치는 간접효과가 유의한 것으로 나타났다(.348, Bias-corrected $\mathrm{CI}=.228 \sim .474)$ 즉, 어머니의 놀 이성은 유아의 놀이성을 매개로 유아의 정서조절을 예측하는 완전매개모형으로 나타났다.

다음으로 어머니의 놀이성과 어머니의 공감적 정서반응의 상호작용 변수는 유아의 놀이성에 유의미한 영향을 주지 않는 것으로 나타났다. 이는 매개된 조절효과 검증에서 조절효과가 통계적으로 유의미하여야 하는 조건이 성립되지 않음을 알 수 있다. 즉, 어머니 집단의 경우에는 매개효과와 조절효과가 결 합된 매개된 조절효과가 유의하지 않음을 의미한다. 
Table 10

Path Estimate of Latent Variables

\begin{tabular}{lccccc}
\hline \multicolumn{1}{c}{ Path of latent variables } & $B$ & $\beta$ & $S E$ & $t$-value & $p$ \\
\hline Mother's playfulness $\rightarrow$ Child's emotion regulation & -.015 & -.011 & .104 & -.143 & .887 \\
Mother's playfulness $\rightarrow$ Child's playfulness & 2.395 & .463 & .437 & 5.479 \\
Child's playfulness $\rightarrow$ Child's emotion regulation & .195 & .752 & .047 & 4.109 & .000 \\
\hline
\end{tabular}

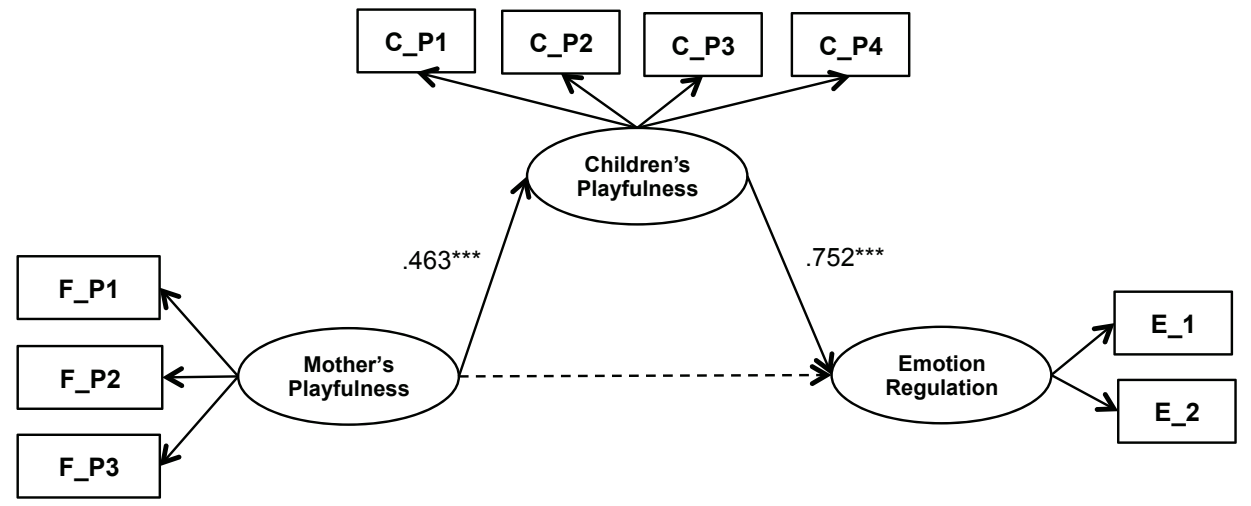

Figure 7. The mediated model.

${ }^{* * *} p<.001$.

\section{Discussion}

본 연구는 유아의 정서조절에 아버지와 어머니의 놀이성이 영 향을 미치는 관계에서 유아의 놀이성이 매개할 것이라는 가설 과 아버지와 어머니의 공감적 정서반응의 조절효과가 결합된 연구가설 모형을 설정하였다. 이러한 매개된 조절모형을 구조 방정식 모형으로 검증하였다.

연구모델의 분석결과는 첫째, 아버지와 어머니 놀이성과 유아의 정서조절 간 관계에서 유아 놀이성의 매개효과가 나 타났다. 즉, 아버지와 어머니의 놀이성이 높을수록 유아 놀이 성 수준은 높아지고 이는 유아의 정서조절능력에 긍정적 영 향을 미치고 있음을 의미한다. 이러한 결과는 어머니의 놀이 성과 유아의 놀이성이 유아의 정서능력 증진에 미치는 요인임 을 밝힌 선행연구 결과(Y.-H. Kim, 2013; Shin \& Woo, 2012)와 일치한다. 영아를 대상으로 한 연구이지만 아버지의 놀이성과 영아의 놀이성이 정서발달에 영향을 미친다는 결과(S. I. Yoon, 2017)와도 맥을 같이한다. 뿐만 아니라 본 연구결과 아버지, 어머니 집단 모두 완전매개효과가 나타났다. 이는 유아의 정 서능력에 영향을 미치는 어머니, 유아의 놀이성 요인을 동시 에 고려했을 때 유아 놀이성의 독립적 영향력이 더 큰 것으로 나타난 연구(Y.-H. Kim, 2013)를 지지하는 결과이다. 아버지와 어머니의 놀이성도 자녀의 정서능력을 높이기 위한 중요한 환
경적 요인이지만, 직접효과보다는 유아의 개인내적 성향인 놀 이성에 영향을 주어 유아의 정서조절로 이어지는 간접효과가 유의미함을 알 수 있다. 즉, 아버지와 어머니가 재미와 자유로 움, 긍정적으로 상황을 대응하는 성향이 높을수록 유아기 자 녀의 놀이에 적극적이고 즐겁게 참여할 가능성이 높고, 이는 유아가 놀이에서 즐거움을 느끼며 놀이를 확장하고 자발적 표 현이 많아지는데 도움을 줄 수 있다. 이러한 유아의 놀이성은 높은 정서조절능력으로 이어짐을 시사한다.

둘째, 아버지의 놀이성과 유아의 놀이성 간 관계에서 공감 적 정서반응의 조절효과가 유의하게 나타났으며 아버지의 공 감적 정서반응은 대립효과를 보이는 것으로 나타났다. 아버 지의 놀이성이 낮을수록 아이의 놀이성도 감소하는데 아버지 의 공감적 정서반응이 적을 경우 유아의 놀이성은 더 감소하 는 것으로 나타났다. 다시 말해, 아버지가 유머와 즐거움을 지 향하는 성향이 부족한 경우라도 유아에게 공감적 정서반응을 많이 한다면 아이의 즐거움, 자발적 표현 등의 놀이성이 높아 짐을 의미한다. 이러한 결과는 아버지의 놀이성이 유아의 놀 이성을 일관적으로 설명하지 못했던 선행연구들의 결과를 보 완해 줄 수 있음을 시사한다. 또한, 유아의 놀이성은 양육자와 자녀 관계가 기반이 되며(Youell, 2008), 아버지-자녀 간 긍정적 상호작용과 자녀의 정서표현에 대한 부모 반응에 영향을 받 는다는 선행연구(W. Kim \& Kim, 2012; Nam, 2005)와 일맥상 
통한다. 부모와 자녀는 ‘함께’ 하면서 정서적 경험을 공유할 때 놀이가 더 풍부해지고 의미가 생긴다(Trevarthen, 2011). 유아 가 긍정적 상호작용을 경험하게 되면 부모와 자녀 간 힘의 차 이를 극복하는데 도움이 되고 이를 통해 유아의 즐거움과 창 의성, 인지적 융통성이 증진된다(Singer, 2013).

상기한 관점에 근거하여 아버지의 놀이성과 유아의 놀이 성 관계에서 아버지가 유아에게 보이는 공감적 정서반응은 중재역할을 하고 있는 것으로 해석된다. 이는 공감적 정서반 응이 자녀의 상황과 요구에 공감할 수 있는 능력이므로(Y.-J. Jo, 2010; Smith, 2006), 부모의 애정적, 허용적 양육태도에 영 향을 주고 이를 통해 유아의 놀이성이 촉진된다(Christopher, Saunders, Jacobvitz, Burton, \& Hazen, 2013; Jung, Kim, \& Lee, 2015)는 선행연구 결과를 지지한다.

셋째, 아버지의 놀이성, 공감적 정서반응 그리고 아버지의 놀이성과 공감적 정서반응의 상호작용 변수가 유아의 정서조 절에 미치는 영향에서 유아의 놀이성이 매개변수로 투입된 매 개된 조절효과가 통계적으로 유의하게 나타났다. 이와 같은 결과는 아버지의 놀이성이 부족하지만 자녀에게 공감적 정서 반응을 빈번하게 보일 경우 유아의 놀이성을 높여 정서조절능 력에도 긍정적 영향을 줄 가능성을 의미한다. 특히, 유아의 놀 이성에 아버지의 놀이성과 아버지의 공감적 정서반응의 상호 작용 효과가 유의미하고 유아의 놀이성은 준거변수인 유아의 정서조절로 이어지는 결과를 통해 공감적 정서반응의 중요성 을 시사한다. 즉, 아버지의 공감적 정서반응을 강화하여 유아 의 놀이성과 정서조절 능력을 증진할 수 있는 가능성에 주목 해야 할 것이다.

이를 논의하기 위해 놀이치료 분야의 연구결과를 고려해 보고자 한다. 놀이성이 높은 치료자는 놀이에서 내담아동이 감정을 표출할 수 있게 이끄는 경향이 더 높으며, 본질적인 즐거운 감정을 갖고 자발적으로 놀이를 할 수 있도록 돕는다 (Wierzbicki \& Salyer, 1991). 또한, 놀이치료사의 공감적 정서 반응과 격려 또는 지지적 반응을 통해 내담아동과 치료적 동 맹이 증진된다(Shaefer \& Greenberg, 1997). 이러한 긍정적 치 료관계를 지속적으로 경험한 내담아동들은 놀이성이 촉진된 다. 예를 들어 놀이치료실에 오는 관계에 어려움이 있는 내담 아동 대부분은 빈약한 놀이행동을 보이며 놀이성이 취약함을 발견할 수 있다. 이는 유아의 놀이성은 건강한 관계를 기반으 로 증진됨을 의미한다(Youell, 2008), 놀이성은 억압되거나 차 단된 감정, 숨기고 싶은 감정들과 접촉 할 수 있게 해주는 역할 을 한다(Landreth, 2011). 이를 통해 아동은 자신의 정서를 인 식하고 표현하며 이를 조절해 나가는 능력을 키워나가게 된
다. 이와 같은 관점에서 유아의 정서조절능력에 도움을 주기 위해서는 아버지의 공감적 정서반응을 증진하여 유아의 놀이 성을 향상시킬 수 있는 개입이 필요함을 시사하는 바이다.

마지막으로 아버지 집단과 다르게 어머니의 놀이성, 공감 적 정서반응 그리고 어머니의 놀이성과 공감적 정서반응의 상 호작용 변수가 유아의 정서조절에 미치는 영향에서 유아의 놀 이성이 매개변수로 투입된 매개된 조절효과는 유의미하지 않 게 나타났다. 이러한 결과는 어머니의 놀이성과 아버지의 놀 이성 선행연구 결과를 비교해서 논의해 볼 필요가 있겠다.

아버지 놀이성에 대한 선행연구에서 나타난 특징 중 하나는 놀이성의 하위요인 중 '재미탐닉적', '쾌활성' 성향이 두드러지 게 높았다(Ahn, 2000; K. S. Kim \& Park, 2002; S. H. Lim, 2017). 반면, 이러한 아버지의 쾌활함이 높을수록 유아의 놀이성은 감 소하는 부적 상관관계가 나타나기도 하였고, 아버지와 어머니 의 놀이성을 동시에 고려했을 때 어머니의 놀이성 총점과 하위 요인은 유아의 놀이성에 영향을 주는 것에 반해 아버지는 쾌활 성 만이 유아의 놀이성에 유의미한 영향을 주고 있었다(Bu \& Kim, 2009; M. S. Lee, 2011). 이는 아버지의 쾌활함과 재미탐닉 적 특성이 유아가 표현하는 정서와 일치하지 않았을 경우 자녀 와의 상호작용이 지속되지 못할 가능성을 고려해 볼 수 있겠 다. 즉, 앞서 언급하였듯이 유아의 놀이성은 부모-자녀의 긍정 적 상호작용과 유아의 정서표현에 대한 부모의 지지반응으로 촉진되는데, 아버지가 아이의 정서표현을 공감하지 못하고 재 미와 쾌활함으로만 감정을 축소하거나 전환시키려 한다면 유 아는 수용 받지 못하는 경험을 하게 된다. 이는 유아의 자발적 표현, 주도적 참여, 즐거움의 표현 등을 유지, 지속하기 어려우 며 놀이를 확장하는데도 방해 요인이 될 수 있다.

따라서 부-자녀 관계에서는 아버지의 공감적 정서반응이 중 재역할을 함으로써 유아의 놀이성에 완화효과를 보이는 것으 로 추측하는 바이다. 이는 직접적으로 비교할 선행연구가 부 족하지만, 양육태도와 유아의 놀이성 간 관계에서 아버지와 어 머니의 차이를 살펴본 연구에서 아버지는 애정적 태도, 어머니 는 통제적 태도가 유아의 놀이성을 예측하는 요인의 결과(J. S. Park, Lim, \& Park. 2009)를 참고해 볼 수 있겠다. 다시 말해 유 아의 놀이성에 아버지의 지지적, 공감적 반응은 의미 있는 중 재변수이지만 어머니의 경우는 아버지와는 다른 요인이 영향 을 주고 있을 것이라고 추측된다. 이와 관련하여 장애아동 부 모를 대상으로 한 연구이지만 유사한 맥락에서 아버지와 어머 니의 놀이성의 차이를 발견한 연구결과를 통해 논의해보고자 한다. 즉, 아버지의 놀이성이 촉진되는 동기는 놀이 중에 경험 하는 자녀의 웃음, 행복한 표정, 긍정적 반응 등을 통해서였다. 
한편, 어머니는 놀이를 통해 자녀가 발달적으로 필요한 기술들 이 증진되는 경우에 어머니의 상호작용이 늘어났고 이는 유아 의 놀이성 향상으로 이어졌다(Roman-Oyola et al., 2018). 상기 한 선행연구들을 근거로 아버지는 자녀와 애정적, 공감적 관계 를 통해 유아의 즐거움과 자발적 표현을 증진시키고, 어머니는 자녀와 결과 지향적, 성취경험을 통해 유아의 주도적, 인지적 융통성을 증진시키는 것으로 해석해 볼 수 있겠다.

또한, 본 연구결과는 어머니와 아버지의 양육패턴의 차이 와도 관련이 있을 가능성이 예상된다. 아버지보다 어머니는 일상적인 양육활동(예: 목욕, 음식준비 등)에서 자녀와 상호작 용하는 시간이 많은 편이며(Craig, 2006; Hook \& Wolfe, 2012; Yeung, Sandberg, Davis-Kean, \& Hofferth, 2001), 어머니는 유 아에게 구조화와 교육 및 훈육적인 상황에서 공감적 상호작 용을 하는 것으로 나타났다(John, Halliburton, \& Humphrey, 2013). 반면 아버지는 다른 양육활동에 비해 자녀와 놀이 활동 에 시간을 많이 보내며(Mehall, Spinrad, Eisenberg, \& Gaertner, 2009), 놀이에서는 자녀의 또래와 놀이하는 것처럼 수평적 인 상호작용이 많았다(John et al., 2013; Russell, Petit, \& Mize, 1998). 따라서 어머니의 경우 자녀와 놀이 보다는 일상적 상황 에서 그리고 아버지는 자녀와의 놀이 상황에서 상호작용이 빈 번하고, 공감적 태도가 중요한 역할을 하는 것으로 추론해 볼 수 있겠다. 이와 관련하여 부모의 양육행동 뿐만 아니라 '놀이 의 질' 즉, 부모-자녀 놀이 상호작용에서 '부모의 놀이성'이 유 아의 부정적 정서에 중요한 영향을 미쳤고, 민감성과 구조화 된 양육태도가 부족하더라도 부모의 놀이성이 높을 경우 유 아의 부정적 정서를 낮추는 조절효과가 나타났다(Menashe $\&$ Atzaba-Poria, 2017). 이를 고려해 볼 때, 유아의 놀이성을 향상 시키고 이를 통해 유아의 높은 정서조절로 이어지기 위해서는 어머니의 경우 자녀와의 놀이 시간을 확보하고 어머니의 놀 이성을 향상 시키는 개입이 필요하며, 아버지는 놀이성과 공 감적 정서반응을 증진하는 개입이 필요함을 시사하는 바이다. 이러한 해석의 타당성 검증을 위해서는 아버지, 어머니의 놀 이성과 유아의 놀이성 간 관계에서 부모-자녀 놀이 상호작용 의 특징을 탐색하는 추후 연구가 이루어질 필요성이 있다.

본 연구는 유아의 정서조절 능력을 촉진하는 개인내적, 환 경적 요인의 경로를 검증하였다는데 의의가 있다. 놀이가 곧 언어이고 학습이며 일상인 유아기의 발달적 특징을 고려해 볼 때, 유아의 정서조절에 영향을 미치는 유아의 놀이성과 아버 지, 어머니의 놀이성 간 관련성 검증은 시사하는 바가 크다. 특 히, 아버지의 놀이성과 공감적 정서 반응의 상호작용 효과가 유아의 놀이성에 영향을 미치고 이는 유아의 정서조절 능력을
증진하는데 도움을 줄 수 있음을 확인 할 수 있었다. 본 연구 결과와 논의를 통해 유아의 놀이성에 영향을 주는 아버지와 어머니의 놀이성과 아버지-자녀, 어머니-자녀의 상호작용 양 상에 대한 차이에 대한 이해를 돕는 기초 자료로 활용하는데 기여할 수 있을 것이다.

본 연구결과와 논의를 토대로 본 연구의 제한점과 추후 연 구를 위한 제언은 다음과 같다. 첫째, 본 연구에서는 아버지와 어머니의 차이를 검증하고자 하는 목적으로 아버지, 어머니 집단만을 구분하여 분석하였다. 그러나 부모의 놀이성과 유아 의 놀이성이 성별에 따라 차이를 보인 연구결과(K. S. Kim \& Park, 2002)를 고려해 볼 때 남아, 여아 집단을 구분하지 않은 결과분석에 한계점이 있고 추후 연구가 필요할 것이다. 둘째, 본 연구에서 논의한 해석의 타당성 검증을 위해서는 추후에 어머니의 놀이성과 유아의 놀이성 간 관계에서 어머니-유아 상호작용의 특징을 탐색하는 추후 연구를 제언하는 바이다. 마지막으로 부모의 놀이성과 유아의 놀이성에 대한 구체적인 양상과 특징을 분석하기 위해서는 부모와 유아의 놀이 상호작 용 관찰과 질적 분석의 연구방법을 적용한 추후 연구가 필요 할 것이다.

\section{Conflict of Interest}

No potential conflict of interest relevant to this article was reported.

\section{References}

\section{In English}

Anderson, J. C., \& Gerbing, D. W. (1988). Structural equation modeling in practice: A review and recommended twostep approach. Psychological Bulletin, 103(3), 411-423. doi:10.1037/0033-2909.103.3.411

Barnett, L. A. (1990). Playfulness: Definition, design, and measurement. Play \& Culture, 3, 319-336.

Boyer, W. A. R. (1997). Enhancing playfulness with sensorial stimulation. Journal of Research in Childhood Education, 12(1), 78-87. doi:10.1080/02568549709594718

Buss, K. A., \& Goldmith, H. H. (1998). Fear and anger regulation in infancy: Effects on the temporal dynamics of affective expression. Child Development, 69(2), 359-374. doi:10.1111/j.1467-8624.1998.tb06195.x 
Cassidy, J. (1994). Emotion regulation: Influences of attachment relationships. Monographs of the Society for Research in Child Development, 59(2-3), 228-249. doi:10.1111j.1540-5834.1994. tb01287.x

Christopher, C., Saunders, R., Jacobvitz, D., Burton, R., \& Hazen, N. (2013). Maternal empathy and changes in mothers' permissiveness as predictors of toddlers' early social competence with peers: A parenting intervention study. Journal of Child and Family Studies, 22(6), 769-778. doi:10.1007/s10826-012-9631-z

Cole, P. M., Ludy, J., \& Sullivan, M. W. (2008). Emotions and the development of childhood depression: Bridging the gap. Child Development Perspectives, 2(3), 141-148. doi:10.1111/ j.1750-8606.2008.00056.x

Craig, L. (2006). Does father care mean fathers share? A comparison of how mothers and fathers in intact families spend time with children. Gender \& Society, 20(2), 259281. doi: $10.1177 / 0891243205285212$

Dawson, J. F. (2014). Moderation in management research: What, why, when and how. Journal of Business and Psychology, 29, $1-19$.

Dawson, J. F., \& Richter, A. W. (2006). Probing three-way interactions in moderated multiple regression: Development and application of a slope difference test. Journal of Applied Psychology, 91(4), 917-926. doi:10.1037/00219010.91.4.917

Denham, S. A. (2006). Social-emotional competence as support for school readiness: What is it and how do we assess it? Early Education and Development, 17(1), 57-89. doi:10.1207/ s15566935eed1701_4

Fairchild, A. J., \& MacKinnon, D. P. (2009). A general model for testing mediation and moderation effects. Prevention Science, 10(2), 87-99. doi:10.1007/s11121-008-0109-6

Fox, N. A., \& Calkins, S. D. (2003). The development of selfcontrol of emotion: Intrinsic and extrinsic influences. Motivation and Emotion, 27(1), 7-26. doi:10.1023/ a: 1023622324898

Gleason, T. R. (2005). Mothers' and fathers' attitudes regarding pretend play in the context of imaginary companions and of child gender. Merill-Palmer Quarterly, 51(4), 412-436. doi:10.1353/mpq.2005.0022

Glynn, M. A., \& Webster, J. (1992). The adult playfulness scale: An initial assessment. Psychological Reports, 71(1), 83-103. doi:10.2466/pr0.1992.71.1.83

Hayes, A. F. (2013). Introduction to mediation, moderation, and conditional process analysis: A regression-based approach. New York: The Guilford Press.

Hook, J. L., \& Wolfe, C. M. (2012). New fathers? Residential fathers' time with children in four countries. Journal of Family Issues, 33(4), 415-450. doi:10.1177/0192513x11425779
John, A., Halliburton, A., \& Humphrey, J. (2013). Child-mother and child-father play interaction patterns with preschoolers. Early Child Development and Care, 183(3-4), 483-497. doi: 10.1080/03004430.2012.711595

Kelly, K. J., \& Metcalfe, J. (2011). Metacognition of emotional face recognition. Emotion, 11(4), 896-906. doi:10.1037/ a0023746

Kishton, J. M., \& Widaman, K. F. (1994). Unidimensional versus domain representative parceling of questionnaire items: An empirical example. Educational and Psychology Measurement, 54(3), 757-765. doi:10.1177/0013164494054003022

Landreth, G. L. (2011). Play therapy: The art of the relationship (3rd ed.). New York: Brunner-Routledge.

Little, T. D., Card, N. A., Bovaird, J. A., Preacher, K. J., \& Crandall, C. S. (2007). Structural equation modeling of mediation and moderation with contextual factors. In $\mathrm{T}$. D. Little, J. A. Bovaird, \& N. A. Card (Eds.), Modeling contextual effects in longitudinal studies (pp. 222-226). Mahwah, NJ: Lawrence Erlbaum Associates.

Menashe-Greinberg, A., \& Atzaba-Poria, N. (2017). Motherchild and father-child play interaction: The importance of parental playfulness as a moderator of the links between parental behavior and child negativity. Infant Mental Health Journal, 38(6), 772-784. doi:10.1002/imhj.21678

Mehall, K. G., Spinrad, T. L., Eisenberg, N., \& Gaertner, B. M. (2009). Examining the relations of infant temperament and couples' marital satisfaction to mother and father involvement: A longitudinal study. Fathering, 7(1), 23-48. doi:10.3149/fth.0701.23

Morgan-Lopez, A. A., \& MacKinnon, D. P. (2006). Demonstration and evaluation of a method for assessing mediated moderation. Behavior Research Methods, 38(1), 77-87. doi:10.3758/bf03192752

Muller, D., Judd, C. M., \& Yzerbyt, V. Y. (2005). When moderation is mediated and mediation is moderated. Journal of Personality and Social Psychology, 89(6), 852-863. doi:10.1037/0022-3514.89.6.852

Partridge, T., \& Lerner, J. V. (2007). A latent growth-curve approach to difficult temperament. Infant and Child Development, 16(3), 255-265. doi:10.1002/icd.465

Ping, R. A. (1995a). A Parsimonious estimating technique for interaction and quadratic latent variables. Journal of Marketing Research, 32(3), 336-347. doi:10.2307/3151985

Ping, R. A. (1995b). Latent variable interaction and quadratic effect estimation: A two-step technique using structural equation analysis. Psychological Bulletin, 119. 166-175. doi:10.1037//0033-2909.119.1.166

Preacher, K. J., Rucker, D. D., \& Hayes, A. F. (2007). Addressing moderated mediation hypotheses: Theory, methods, and prescriptions. Multivariate Behavioral Research, 42(1), 185- 
227. doi:10.1080/00273170701341316

Preacher, K. J., \& Selig, J. P. (2012). Advantages of monte carlo confidence intervals for indirect effects. Communication Methods and Measures, 6(2), 77-98. doi:10.1080/19312458 .2012 .679848

Román-Oyola, R., Figueroa-Feliciano, V., Torres-Martínez, Y., Torres-Vélez, J., Encarnación-Pizarro, K., FragosoPagán, S., \& Torres-Colón, L. (2018). Play, playfulness and self-efficacy: Parental experiences with children on the autism spectrum. Occupational Therapy, 2018, 1-10. doi: $10.1155 / 2018 / 4636780$

Russell, A., Petit, G. S., \& Mize, J. (1998). Horizontal qualities in parent-child relationships: Parallels with and possible consequences for children's peer relationships. Developmental Review, 18(3), 313-352. doi:10.1006/drev. 1997.0466

Schaefer, C., \& Greenberg, R. (1997). Measurement of playfulness: A neglected therapist variable. International Journal of Play Therapy, 6(2), 21-31. doi:10.1037/h0089406

Shen, X., Chick, G., \& Pitas, N. A. (2017). From playful parents to adaptable children: a structural equation model of the relationships between playfulness and adaptability among young adults and their parents. International Journal of Play, 6(3), 244-254. doi:10.1080/21594937.2017.1382983

Shields, A., \& Ciccihetti, D. (1997). Emotion regulation among school-age children: The development and validation of a new criterion Q-sort scale. Developmental Psychology, 33(6), 906-916. doi:10.1037/0012-1649.33.6.906

Shrout, P. E., \& Bolger, N. (2002). Mediation in experimental and nonexperimental studies: new procedures and recommendations. Psychologica Methods, 7(4), 422-445. doi:10.1037/1082989x.7.4.422

Singer, E. (2013). Play and playfulness, basic features of early childhood education. European Early Childhood Education Research Journal, 21(2), 172-184. doi:10.1080/135029 $3 x .2013 .789198$

Smith, A. (2006). Cognitive empathy and emotional empathy in human behavior and evolution. The Psychological Record, 56(1), 3-21. doi:10.1007/bf03395534

Suveg, C., Southam-Gerow, M. A., Goodman, K. L., \& Kendall, P. C. (2007). The role of emotion theory and research in child therapy development. Clinical Psychology: Science and Practice, 14(4), 358-371. doi:10.1111/j.14682850.2007.00096.x

Trevarthen, C. (2011). What young children give to their learning, making education work to sustain a community and its culture. European Early Childhood Education Research Journal, 19(2), 173-193. doi:10.1080/135029 3x.2011.574405

Wierzbicki, M., \& Salyer, M. K. (1991). Depression and engagement in pleasant and unpleasant activities in normal children. Journal of Clinical Psychology, 47(4), 499505. doi:10.1002/1097-4679(199107)47:4<499::aidjclp2270470405>3.0.co;2-q

Yeung, W. J., Sandberg, J. F., Davis-Kean, P. E., \& Hofferth, S. L. (2001). Children's time with fathers in intact families. Journal of Marriage and Family, 63(1), 136-154. doi:10.1111/j.1741-3737.2001.00136.x

Youell, B. (2008). The importance of play and playfulness. European Journal of Psychotherapy \& Counselling, 10(2), 121-129. doi:10.1080/13642530802076193

\section{In Korean}

Ahn, S. J. (2000). A Study on the fathering practices and father's playfulness with his child in early childhood. Korean Journal of Play Therapy, 3(2), 78-85.

Bae, B. R. (2015). (SPSS/Amoss/LISREL/SmartPLSe uihan) Jojeolhyogwa mit maegaehyogwabunseok [(SPSS/Amoss/ LISREL/SmartPLS에 의한) 조절효과 및 매개효과 분석)]. Seoul: Chungram.

Bae, M. K. (2012). Relationship of temperament and playfulness to peer-con flict-resolving strategies among preschoolers. Journal of Early Childhood Education \& Educare Welfare, 16(2), 197-220.

Bu, J. M., \& Kim, J. S. (2009). Relationship between parents' playfulness and children's playfulness. Korean Journal of Child Psycho Therapy, 4(2), 1-15.

Cho, O. M. (2005). A study on the parents' playfullness and the family functioning with their child in early childhood (Master's thesis). Retrieved from http://www.riss.kr/link?id= T10211085

Cho, Y. I., Kim, J.-H., Han, W.-R., \& Jo, Y.-J. (2015). Differences and combinations of moderation and mediation effects: Definitions and statistical testing. Korean Journal of Clinical Psychology, 34(4), 1113-1131.

Choi, E. A. (2005). A study on the relationships of young children's temperament, mother's mother-child interaction behaviors and children's playfulness (Master's thesis). Retrieved from http:// www.riss.kr/link?id=T9766228

Choi, Y. S. (2018). The effect of parent's play participation and children's playfulness on children's happiness (Master's thesis). Retrieved from http://www.riss.kr/link?id=T14744923.

Han, M.-H. (2002). The relationships between children's creativity, playfulness and emotional intelligence (Master's thesis). Retrieved from http://www.riss.kr/link?id=T10212825

Hwang, J. (2012). An analysis of father's playfulness, play participation, child rearing participation, and young children's self-regulation (Master's thesis). Retrieved from http://www. riss.kr/link?id=T10212825 
Jo, Y.-J. (2010). Development and validation of parental empathy inventory perceived by adolescents. Korean Journal of Youth Studies, 17(4), 127-156.

Jo, J. M. (2013). The relationship of social behavior, emotional regulation and aggression according to sex and age of children (Master's thesis). Retrieved from http://www.riss.kr/ link?id=T13237468

Jung, M. R., Kim, M. J., \& Lee, B. S. (2015). The effect of mothers' empathy and parenting attitude on children's playfulness. The Journal of Eco Early Childhood Education \& Care, 14(1), 101-122.

Kim, C. S. (2010). The relationship of young children's self-regulation and parents' participation of play (Master's thesis). Retrieved from http://www.riss.kr/link?id=T12172689

Kim, C. Y. (2007). The musical education research through brain scientific access of the intellectual development process (Master's thesis) Retrieved from http://www.riss.kr/ link?id=T10932156

Kim, G. S. (2014). (Amos 18.0) Gujobangjeongsingmohyeong bunseok [(Amos 18.0) 구조방정식모형 분석]. Seoul: Hannarae Acedemy.

Kim, H. N., \& Lee, K. O. (2017). A study on the relationship between mother's playfulness and infant's playfulness and emotional control. Poster presented at the Annual Meeting of Korea Association of Child Studies, Seoul, Korea. Retrieved from http://www.riss.kr/link?id=A104361492

Kim, J. S. (2011). The effect of fathers' playfulness, parental efficacy and parenting behaviors on playfulness of young children (Doctoral dissertation). Retrieved from http://www.riss.kr/ link?id=T12319323

Kim, J.-Y. (2007). The effects of preschooler's temperament, marital conflict, and preschooler's emotion regulation on problem behaviors (Master's thesis). Retrieved from http://www.riss. $\mathrm{kr} / \mathrm{link}$ ?id=T11038811

Kim, J.-Y., Doh, H.-S., \& Kim, M.-J. (2008). Problem behavior of preschool children: The influence of marital conflict and of children's temperament and emotion regulation. Korean Journal of Child Studies, 29(5), 133-150.

Kim, K.-H. (2004). Relationship between temperament and emotion regulation with negative emotion. Korean Journal of Child Studies, 25(6), 1-14.

Kim, K. S. (2002). The relationship between fathers' rearing behaviors, playfulness, and young children's playfulness (Master's thesis). Retrieved from http://www.riss.kr/link?id=T8875241

Kim, K. S., \& Park, I. J. (2002). The relationship between fathers' rearing behaviors, playfulness, and young children's playfulness. Korean Journal of Play Therapy, 5(2), 27-43.

Kim, M. S., Kim, G. S., \& Park, C. H. (2012). The development and validity of the children's playfulness rating scale. Korean Journal of Child Studies, 33(2), 69-89. doi:10.5723/ kjcs.2012.33.2.69

Kim, S.-M., \& Choi, J.-A. (2015). The relations among mother's playfulness, child's playfulness, child's self regulation and child's social competence. The Journal of Play Therapy, 19(2), 39-54.

Kim, W., \& Kim, J. (2012). The effect of parental attitude toward young children's emotional expression on their emotional intelligence and playfulness. The Journal of Yeolin Education, 20(3), 71-92.

Kim, Y.-H. (2013). The effects of young children's and mothers' playfulness on children's emotional intelligence. Journal of The Korea association of Child Care and Education, 44(3), 217-240.

Kang, D. Y., \& Kim, W. (2018). The effect of mother's emotional socialization behaviors and young children's executive function on young children's emotional regulation ability. The Journal of Korea Open Association for Early Childhood Education, 23(1), 259-279. doi:10.20437/KOAECE23-1-10

Lee, J.-W., Lim, W.-S., \& Cho, S.-Y. (2009). The relationship between mothers' belief of play, children's emotional competence and adjustment to preschools. Journal of Educational Studies, 40(3), 149-170.

Lee, M. S. (2011). Effects of parents' play belief and playfulness on children's Playfulness (Master's thesis). Retrieved from http:// www.riss.kr/link?id=T12451100

Lee, S. Y. (2011). The influence of the emotional expression of the parents on children's emotion-control (Master's thesis). Retrieved from http://www. riss.kr/link?id=T12288359

Lim, E., \& Kim, S. (2011). A structural relationship analysis between young children's social competence and emotion regulation ability and related variables according to gender. Journal of Early Childhood Education, 31(4), 5-30. doi:10.18023/kjece.2011.31.4.001

Lim, S. H. (2017). The effects of parent's playfulness and participation time about their children's playing on their children's playfulness (Master's thesis). Retrieved from http://www.riss. $\mathrm{kr} /$ link?id=T14431406

Lim, Y. (2010). The relationship between children's playfulness and self-regulation (Master's thesis). Retrieved from http://www. riss.kr/link?id=T11984051

Nam, D. (2005). Relationship between playfulness of infant and father-infant interaction (Master's thesis). Retrieved from http://www.riss.kr/link?id=T1040338

Oh, S. K. (2011). The difference of emotional regulation and social competence by adult attachment types of children (Master's thesis). Retrieved from http://www.riss.kr/ link?id=T12288405

Park, J. S., Lim, S. H., \& Park, S. Y. (2009). Effects of child's temperament, mother's parenting behavior, and child's emotion regulation on child aggression and social withdrawal. Korean Journal of Child 
Studies, 30(3), 85-98.

Shin, S. H., \& Woo, S.-K. (2012). Relationships among mothers' playfulness, young children's emotional competence, and social competence. Korean Living Science Association, 2012(11), 244-245.

Song, C.-B. (2009). A study of the influence of parental role intelligence upon children's playfulness and social competence (Master's thesis). Retrieved from http://www.riss.kr/ link?id=T11632921

Woo, S.-K. (2013). Young children's emotional competence by sex, playfulness and mother's playfulness. Korean Journal of Child Care and Education, 80, 153-174.

Yoon, S. \& Sung, J. (2014). The effects of mothers' parenting efficacy on children's emotional regulation: The role of mothers' perception of fathers' involvement in child care. Korean Journal of Child Studies 35(4), 199-222. doi:10.5723/kjcs.2014.35.4.199

Yoon, S. I. (2017). Effects of father's playfulness on the playfulness and the socioemotional development of two-year-old infants (Master's thesis). Retrieved from http://www.riss.kr/ link?id=T14916436

You, M. (2008). The effects of maternal beliefs about play and emotional expressiveness on children's playfulness (Master's thesis). Retrieved from http://www.riss.kr/ link?id=T11380983

Yu, J. P. (2012). Gujobangjeongsingmodel gaenyeomgwa ihae: Amos 4.0-20.0 gongyong [구조방정식모델 개념과 이해: Amos 4.0-20.0 공용]. Seoul: Hannarae Academy.

Yu, J. P. (2015). The item parceling bias of multi-dimensionality in the structural equation modeling. Korean Business Review, 44(4), 1131-1147. doi:10.17287/kmr.2015.44.4.1131

\section{Ji-Hyun Oh \\ http://orcid.org/0000-0001-9846-4310 \\ Shee Hyeong Lim https://orcid.org/0000-0002-7444-059X}

Received October 31, 2018 Revision received November 26, 2018 Accepted December 17, 2018 